\title{
IMPLEMENTASI SISTEM INFORMASI DESA (SID) DAN INSTALASI VOICE SERVER GUNA MENINGKATKAN PARTISIPASI WARGA DESA BAMBAN SELATAN DALAM MEMBANGUN DESA
}

\author{
Rahimi Fitri ${ }^{1}$, Arifin Noor Asyikin ${ }^{2}$, Agus Setiyo Budi $N^{3}$ \\ Politeknik Negeri Banjarmasin ${ }^{1,2,3}$ \\ rahimi fitri@poliban.ac.id ${ }^{1}$ \\ arifin@poliban.ac.id ${ }^{2}$ \\ agus_sbn@poliban.ac.id ${ }^{3}$
}

\begin{abstract}
The application of ICT-based Village Information System (SID) as a tool for village officials in serving the community is part of the e-Government implementation program launched by the government as stipulated in the Presidential Instruction No. 6 of 2001 concerning telematics in government and Presidential Instruction No. 3 of 2003 concerning the implementation of electronic governance in Indonesia.

Various problems that arise when managing village data such as problems in administering village data and population data, correspondence data management, management of parcel data and most importantly are decision making of village apparatus as well as input in village development planning can be completed using SID. can be used by villages so that good governance is formed.

South Bamban Village, Angkinang Subdistrict, Hulu Sungai Selatan District is the smallest part of the administrative administrative system in Indonesia, which has an obligation to be able to keep up with information technology (ICT) development and continue to improve its ability to manage village population administration data. At present the south Bamban village has not used SID to support work related to village governance. Various problems often arise either from the side of the village apparatus or from the village community, one of the problems is the difficulty in finding population data, and the lack of citizen participation in providing advice on activities that have been carried out.

With the implementation of community service activities in the form of the implementation of the village information system and the installation of voice servers in the South Bamban Village, it is expected to solve the problems in the village office and improve the performance of village officials in serving the community, as well as increasing citizen participation to jointly develop villages.
\end{abstract}

Keywords: Village Information Systems, ICT, e-Government, voice servers

\begin{abstract}
ABSTRAK
Penerapan Sistem Informasi Desa (SID) berbasis TIK sebagai alat bantu bagi perangkat desa dalam melayani masyarakat adalah bagian dari program penerapan e-Government yang telah dicanangkan oleh pemerintah sebagaimana yang tertuang dalam Amanat Inpres No. 6 tahun 2001 tentang telematika dalam pemerintahan dan Inpres No. 3 tahun 2003 tentang penyelenggaraan tata kelola pemerintahan secara elektronis di Indonesia.

Beragam permasalahan yang muncul pada saat pengelolaan data desa seperti permasalahan pengadministrasian data desa dan data kependudukan, pengelolaan data surat menyurat, pengelolaan data persil dan yang paling penting adalah pengambilan keputusan perangkat desa serta sebagai masukan dalam perencanaan pembangunan desa dapat
\end{abstract}


diselesaikan dengan menggunakan SID Sistem ini diharapkan dapat digunakan oleh desa sehingga terbentuk tata kelola pemerintahan desa yang baik (good governance).

Desa Bamban Selatan Kecamatan Angkinang Kabupaten Hulu Sungai Selatan merupakan bagian terkecil dari sistem pemerintahan administratif di Indonesia, yang memiliki kewajiban untuk dapat mengikuti perkembangan teknologi informasi (TIK) dan terus meningkatkan kemampuannya didalam mengelola data administrasi kependudukan desa. Saat ini Desa Bamban selatan belum menggunakan SID untuk menunjang pekerjaan yang berkaitan tentang tata kelola desa. Beragam permasalahan kerap muncul salah baik dari sisi perangkat desa maupun dari masyarakat desa, salah satu permasalahan adalah kesulitan dalam pencarian data kependudukan, dan kurangnya partisipasi warga dalam memberikan saran atas kegiatan yang telah dilaksanakan.

Dengan dilaksanakannya kegiatan pengabdian kepada masyarakat berupa implementasi sistem informasi desa dan instalasi voice server di Desa Bamban Selatan diharapkan dapat menyelesaikan permasalahan yang ada di kantor desa serta meningkatkan kinerja dari perangkat desa dalam melayani masyarakat, serta meningkatkan partisipasi warga untuk bersama-sama membangun desa.

Kata Kunci: Sistem Informasi desa, TIK, e-Government, voice server

\section{PENDAHULUAN}

Desa Bamban Selatan merupakan salah satu desa yang terdapat di kecamatan angkinan hulu sungai selatan provinsi kalimantan selatan. Secara geografis desa ini berbatasan dengan desa lainnya, sebelah utara berbatasan dengan desa angkinang kecamatan kandangan, sebelah selatan berbatasan dengan Desa Bamban Kecamatan Haruyan, sebelah timur berbatasan dengan Desa Pakuan Timur Kecamatan Telaga Langsat dan sebelah barat berbatasan dengan Desa Kayu Abang Kecamatan Telaga Langsat.

Mata pencaharian penduduk Desa Bamban Selatan adalah dibidang pertanian dan perkebuanan, dan ada sebagian yang bekerja sebagai pedagang, hal ini tertuang dalam visi dari Desa Bamban selatan yaitu "mewujudkan desa Bamban Selatan menjadi desa mandiri melalui bidang pertanian dan perkebunan".

Desa Bamban Selatan merupakan bagian terkecil dari sistem pemerintahan administratif di Indonesia, yang memiliki kewajiban untuk dapat mengikuti perkembangan teknologi informasi (TIK) dan terus meningkatkan kemampuannya didalam mengelola data administrasi kependudukan desa. Saat ini di desa Bamban selatan sistem pelayanan administrasi kependudukan desa masih banyak yang bersifat konvensional. Hal tersebut berimbas kepada perangkat desa maupun penduduk desa, dimana sering terjadi human error, serta pemborosan waktu dan biaya. Oleh karena itu dibutuhkan suatu sistem yang mengarah ke e-Government untuk mengatasi permasalahan-permasalahan yang ada seperti kesulitan dalam pengelolaan data kependudukan yang mana didalamnya meliputi data penduduk, data mata pencaharian penduduk dan lain sebagainya.

Berdasarkan pada Pasal 86 Undang-undang Desa menyatakan bahwa (UU_6, 2014):

Desa berhak mendapatkan akses informasi melalui sistem informasi Desa yang dikembangkan oleh Pemerintah Daerah Kabupaten/Kota. 
(1) Pemerintah dan Pemerintah Daerah wajib mengembangkan sistem informasi desa dan pembangunan kawasan Perdesaan.

(2) Sistem informasi desa sebagaimana dimaksud pada ayat (2) meliputi fasilitas perangkat keras dan perangkat lunak, jaringan, serta sumber daya manusia.

(3) Sistem informasi Desa sebagaimana dimaksud pada ayat (2) meliputi data Desa, data Pembangunan Desa, Kawasan Perdesaan, serta informasi lain yang berkaitan dengan Pembangunan Desa dan pembangunan Kawasan Perdesaan.

(4) Sistem informasi Desa sebagaimana dimaksud pada ayat (2) dikelola oleh Pemerintah Desa dan dapat diakses oleh masyarakat Desa dan semua pemangku kepentingan.

(5) Pemerintah Daerah Kabupaten/Kota menyediakan informasi perencanaan pembangunan Kabupaten/Kota untuk Desa.

Pengelolaan sistem pemerintahan desa dengan memanfaatkan teknologi informasi dan komunikasi merupakan langkah strategis untuk mewujudkan kesejahteraan masyarakat melalui sistem menejemen penyelenggaraan pemerintahan desa yang efisien transparan dan dapat memberikan manfaat diantaranya mendukung pengambilan keputusan (Saymote, 2014), sebagai masukan dalam perencanaan pembangunan desa (Mayowan, 2016) serta menjadi sarana pertanggungjawaban perangkat desa atas penyelenggaraan pemerintahan, sehingga dapat tercipta pemerintahan yang transparan, akuntabel, dan mandiri dan akan mengurangi kesenjangan digital dan mendorong peningkatan perekonomian masyarakat (Praditya, 2014).

Sistem informasi desa dapat menjadi sarana pertanggungjawaban pemerintah desa atas penyelenggaraan pemerintahan, sehingga akan tercipta pemerintahan yang mandiri, transparan dan akuntabel dan akan mengurangi kesenjangan digital dan mendorong peningkatan perekonomian masyarakat.

Berdasarkan analisis situasi diatas maka dengan dilaksanakannya kegiatan pengabdian kepada masyarakat berupa pendampingan dan penerapan sistem informasi desa di Desa Bamban Selatan diharapkan dapat menyelesaikan permasalahan yang ada di kantor desa serta meningkatkan kinerja dari perangkat desa dalam melayani masyarakat.

\section{METODE KEGIATAN}

Mengingat pengembangan sistem informasi desa ini merupakan sebuah transformasi dari manual menuju terkomputerisasi maka dalam penyusunan dibutuhkan upaya-upaya sistematis yang menyangkut subyek, obyek dan metoda yang terkait dengan proses transformasi tersebut. Berikut tahapan kegiatan yang akan dilaksanakan : 


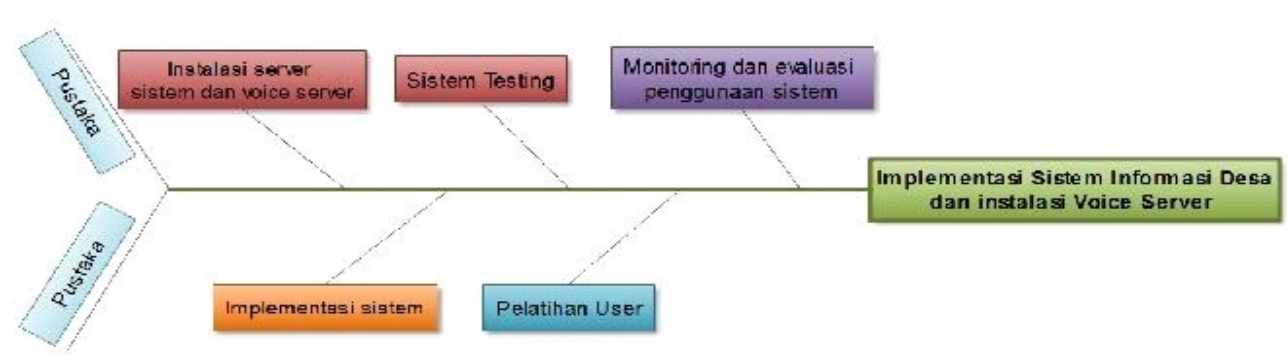

Gambar 1. Tahapan Kegiatan

Berikut ini penjelasan dari tahapan diatas :

1. Persiapan Perangkat

Tim pengabdian menyiapkan perangkat yang akan dipasang di lokasi pengabdian, pada kegiatan ini akan melibatkan tim penelitian dan tenaga teknis dari mahasiswa.

2. Instalasi sistem server dan voice server;

Tahapan ini akan dilakukan proses instalasi server sistem dikantor pemerintahan desa. Instalasi voice server adalah untuk fasilitas tambahan yang diperuntukkan bagi warga desa supaya dapat menggunakan telpon gratis dengan menggunakan wifi.

a. Instalasi Server Pada Kantor Desa

Server sistem informasi desa akan di letakkan diarea kantor desa denga beberapa perangkat jaringan pendukung yaitu router mikrotik yang juga terdapat Wifi didalamnya, sehingga dapat menghubungkan antara 1 PC admin dengan 1 PC layanan secara wireless.

PC layanan akan diletakkan di area pelayanan masyarakat, sehingga masyarakat dapat mengakses sistem (permohonan pembuatan surat, permohonan perbaikan data atau melihat tampilan website desa). Dengan adanya PC layanan yang terkoneksi dengan server SID akan mempercepat pelayanan kepada Masyarakat. Sistem informasi desa hanya berada dalam jaringan intranet. Gambar 2 berikut ini adalah rancangan sistem jaringan dikantor desa yang akan dibangun.

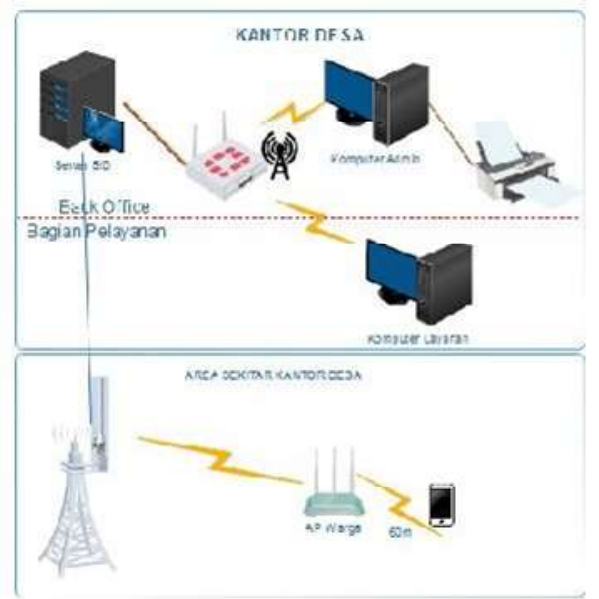

Gambar 2. Rancangan Jaringan di Kantor Desa 
b. Instalasi Jaringan Voice di Area Sekitar Kantor Desa

Instalasi jaringan voice di area sekitar kantor desa meliputi instalasi Akses Point server menggunakan antena omni yang terhubung dengan router yang ada di kantor desa. Selanjutnya instalasi akses point client di dua lokasi yang berbeda. Antena Omni dan Akses point server serta akses point client akan dipasang menggunakan tower agar cakupan area yang dapat terkoneksi cukup luas.

Di area lingkungan warga akan dipasang akses point yang dapat digunakan warga menggunakan handphone yang dapat terkoneksi wifi sehingga seluruh warga yang berada pada area jangkauan dapat saling berkomunikasi. Pada kegiatan ini akan melibatkan perangkat desa dan masyarakat sekitar kantor desa.

Keuntungan dari adanya fasilitas voice server adalah kemudahan berkomunikasi tanpa terkena pulsa ataupun biaya, sehingga diharapkan dapat meningkatkan partisipasi warga dalam membangun desa.

3. Pelatihan User

Pelatihan user dilaksanakan selama 2 hari dimana perangkat desa akan dilatih cara menggunakan sistem baik dari sisi admin maupun dari sisi pengguna. Selain pelatihan penggunaan sistem, perangkat desa akan dilatih penggunaan anti virus, jaringan computer dan instalasi sistem operasi. Peserta dari kegiatan ini adalah perangkat desa dan perwakilan warga

4. Monitoring dan Evaluasi penggunaan sistem

Proses monitoring dan evaluasi dilaksanakan selama proses implementasi sistem. Proses monitoring dapat dilakukan secara jarak jauh dengan perangkat desa dengan cara memonitoring aktifitas dari penggunaan sistem informasi.

\section{HASIL DAN PEMBAHASAN}

A. Implementasi Sistem Informasi Desa di Bamban Selatan

Dalam sistem informasi desa pengguna dalam sistem ini diklasifikasikan menjadi 3 pengguna yaitu administrator yang terdiri dari admin dan master admin, operator dan redaksi / data entri.

Peran yang diperlukan untuk pengoperasian sistem informasi adalah sebagai berikut. Seorang petugas kantor desa bisa saja merangkap beberapa peran,dan sebaliknya suatu peran bisa saja diberikan kepada beberapa petugas, sesuai dengan skala kantor desa dan deskripsi tugas mereka. Berikut ini penjelasan peran dari ketiga pengguna tersebut:

1. Administrator, memiliki peran sebagai berikut :

a. Merencanakan, mengkoordinasikan dan melaksanakan langkahlangkah keamanan untuk melindungi informasi dalam sistem informasi terhadap kerusakan, pemodifikasian atau akses yang tidak sah.

b. Merancang dan membangun deskripsi database secara fisik dan logis dan menentukan pengidentifikasi dari database untuk sistem manajemen atau orang lain secara langsung dalam pengkodean deskripsi 
c. Menguji program atau database, memperbaiki kesalahan dan membuat modifikasi yang diperlukan.

d. Menentukan pengguna dan tingkat akses pengguna untuk setiap segmen dari database

e. Melakukan perbaikan jika terjadi error atau kerusakan pada SID.

f. Meng-onlinekan website desa.

g. Melakukan backup database desa dan folder desa secara rutin.

h. Menyiapkan perangkat-perangkat pendukung (laptop, PC, jaringan).

2. Operator, mempunyai peran sebagai berikut :

a. Memberikan pelayanan kepada masyarakat menggunakan SID

b. Mengubah dan menambah artikel terbaru

c. Mengelola komentar.

d. Mencetak laporan data kependudukan.

e. Memasukan bahan artikel.

f. Memasukan bahan untuk menu (menu statis dan dinamis).

g. Mengelola data penduduk dan profil desa.

h. Melakukan backup database desa dan folder desa secara rutin.

3. Redaksi/ Data Entri mempunyai peran sebagai berikut :

a. Melakukan update berita

b. Mengelola berita

c. Melakukan verifikasi data sebelum dientri.

d. Mengentri data penduduk dan desa.

e. Mengedit data yang sudah dientri (jika terjadi kesalahan data)

f. Membantu menyelesaikan data yang sama (double).

Pembahasan berikut ini akan menampilkan cuplikan gambar dari sistem informasi Desa Bamban Selatan.

1. Tampilan Admin

Gambar 3 berikut ini adalah tampilan awal admin yaitu halaman login.

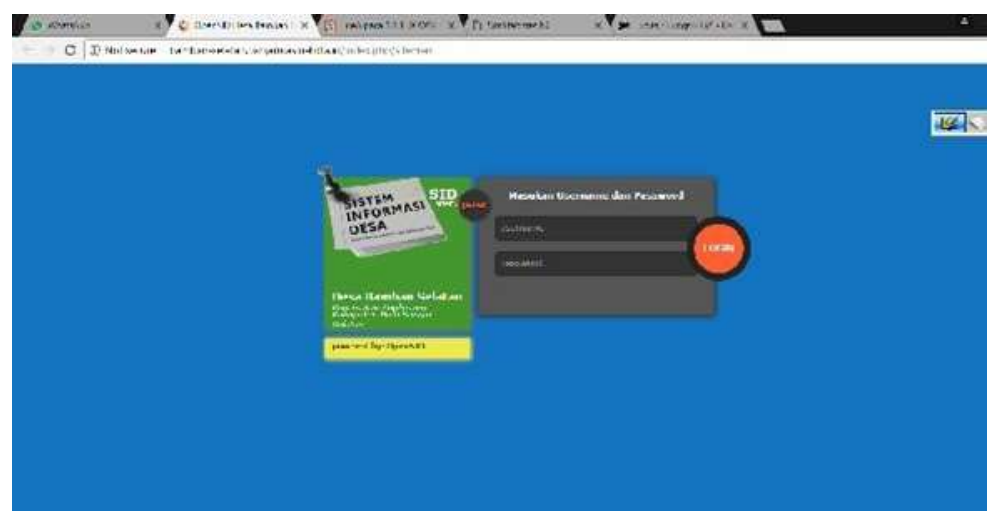

Gambar 3. Tampilan Login Admin

Pada halaman ini admin memasukkan data login, jika login yang dimasukkan salah maka pesan gagal akan ditampilkan.

a. Tampilan Home dari Admin 
Gambar 4 berikut ini adalah halaman home dari halaman admin sistem informasi desa (SID) Desa Bamban Selatan. Pada halaman ini pengguna dapat memilih beberapa fitur seperti melihat identitas desa, melihat identitas pemerintah desa dan informasi tentang sistem informasi desa.

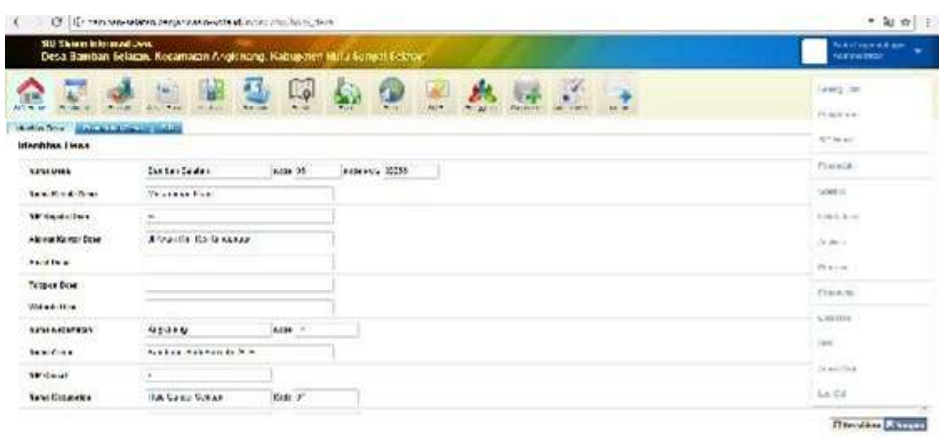

Gambar 4. Tampilan Halaman Home

b. Tampilan Halaman Penduduk

Gambar 5 merupakan tampilan halaman kependudukan yang berisi fitur wilayah kependudukan, keluarga, penduduk, Rumah tangga, Kelompok dan calon pemilih.

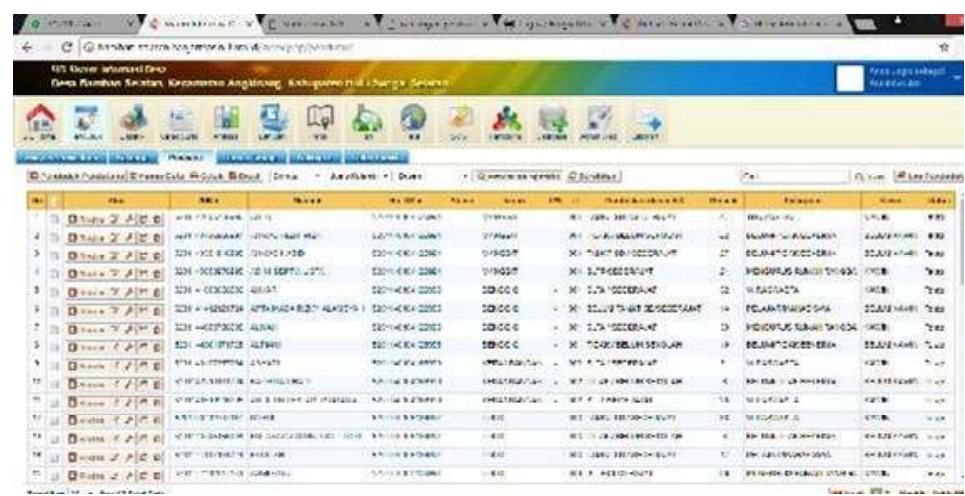

Gambar 5. Tampilan halaman kependudukan

c. Tampilan Halaman Statistik

Pada gambar 6 menunjukkan tampilan statistik penduduk.

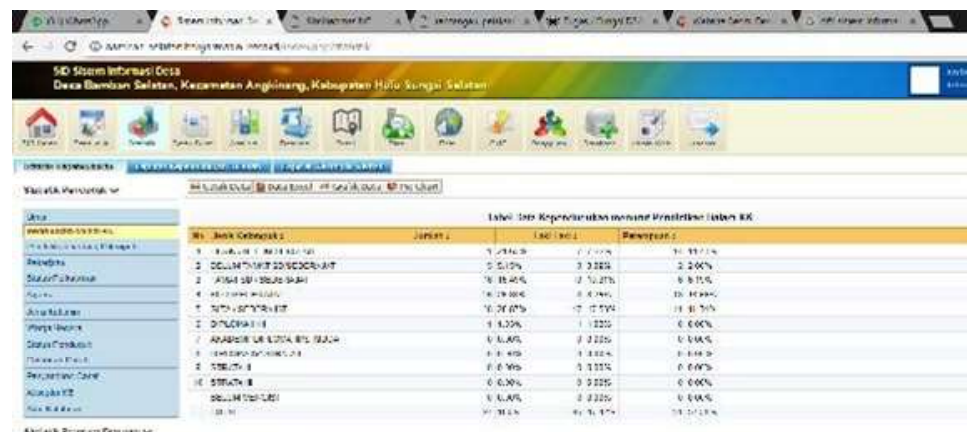

Gambar 6. Tampilan Halaman Statistik 
d. Tampilan halaman Cetak Surat

Pada gambar 7 menunjukkan fitur untuk cetak surat masuk, surat keluar, master surat, dan panduan penggunaan fasilitas ini.

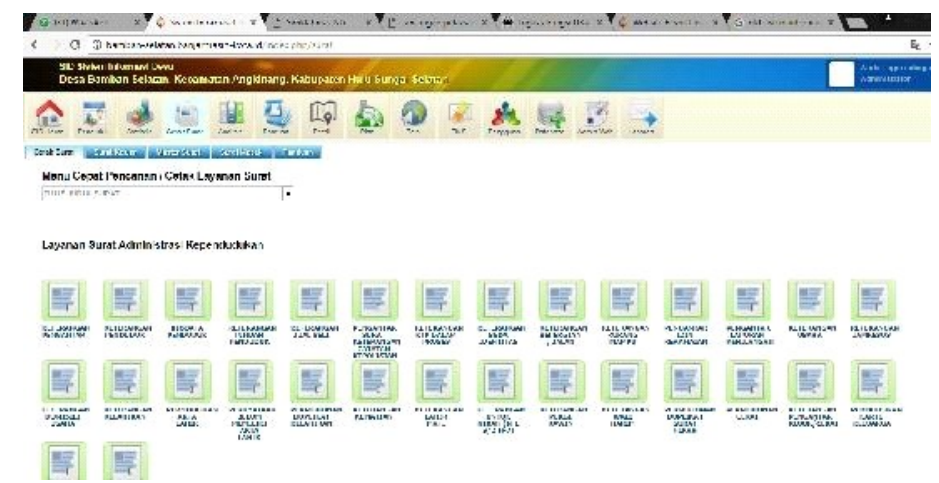

Gambar 7. Tampilan Halaman Cetak Surat

e. Tampilan Halaman Analisis

Pada gambar 8 menunjukkan halaman penyedia modul analisis yang digunakan untuk menganalisa data sensus penduduk

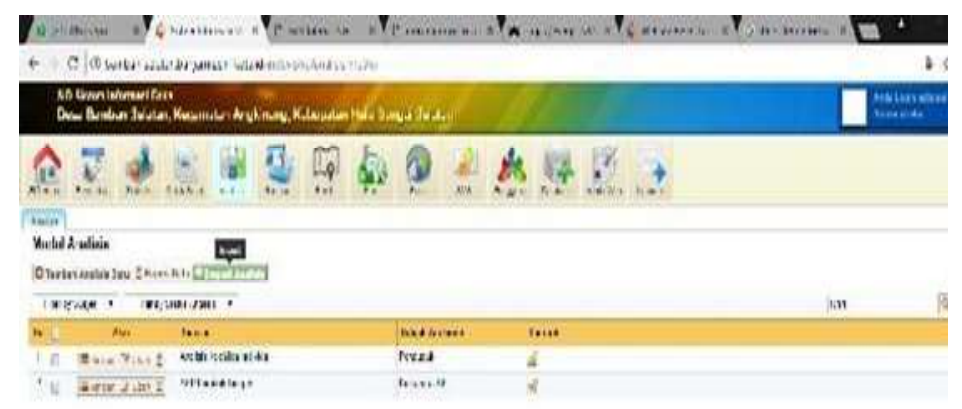

Gambar 8. Tampilan Halaman Analisis

f. Tampilan Halaman Bantuan

Halaman ini merupakan fitur untuk pengelolaan data aktivitas program kerja dan keterlibatan warga, baik secara personal, keluarga, rumah tangga, maupun kelompok/organisasi dapat dilihat pada gambar 9.

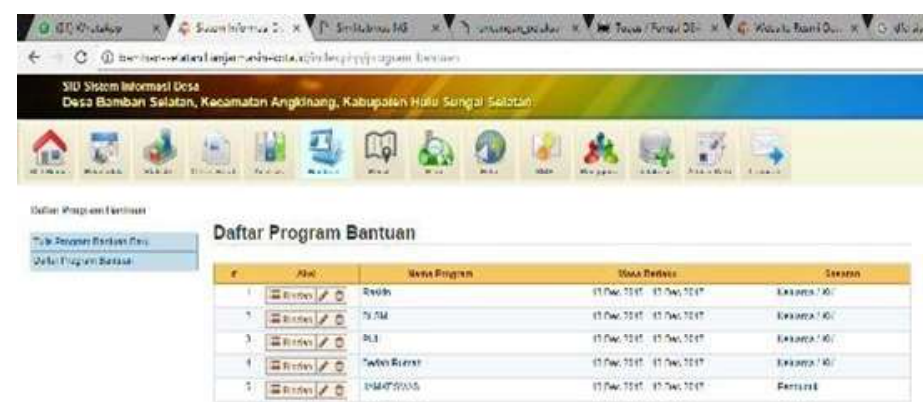

Gambar 9. Tampilan Halaman Bantuan 
B. Implementasi Voice IP (Voip) Server

Berikut ini adalah alur sistem Voip Server bekerja.

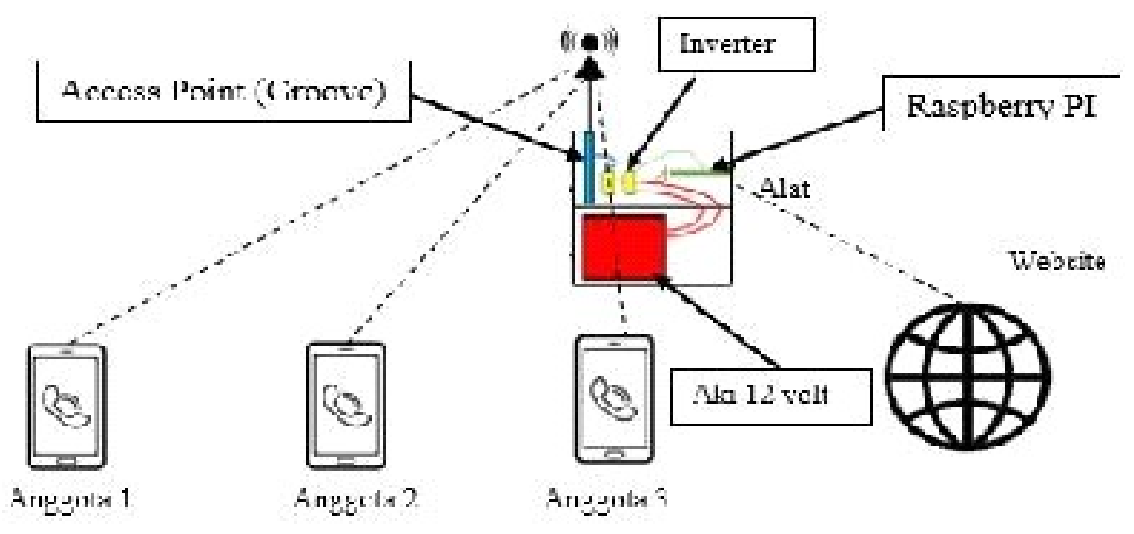

Gambar 10. Alur Kerja Voip Server

Spesifikasi dari kebutuhan dari VoIP server yang dibangun adalah sebagai berikut.

a. Perangkat

Keras

1. Pemancar sinyal : Groove A52

2. Server : Rasberry PI

3. Power supply : Aki 12 Volt

4. Inverter : Mengubah Tegangan (dc ke ac)

b. Perangkat lunak:

1. Zoiper

2. Linux

3. Asterisk

4. XAMPP

Warga yang ingin mengakses VoIP server harus menggunakan handphone android dan mengunduh dan menginstal aplikasi zoiper.

Access point digunakan untuk menyebarkan sinyal kepada warga yang sudah memasang dan memiliki akun yang terdaftar di perangkat lunak Zoiper. Raspberry yang sebelumnya sudah kita pasang Asterisk akan digunakan sebagai server untuk VoIP. Kemudian setiap anggota yang terhubung dapat melakukan pengiriman video dan log panggilan ke website.

Gambar 11 adalah ujicoba server voip yang digunakan untuk kegiatan komunikasi di desa Bamban Selatan. 


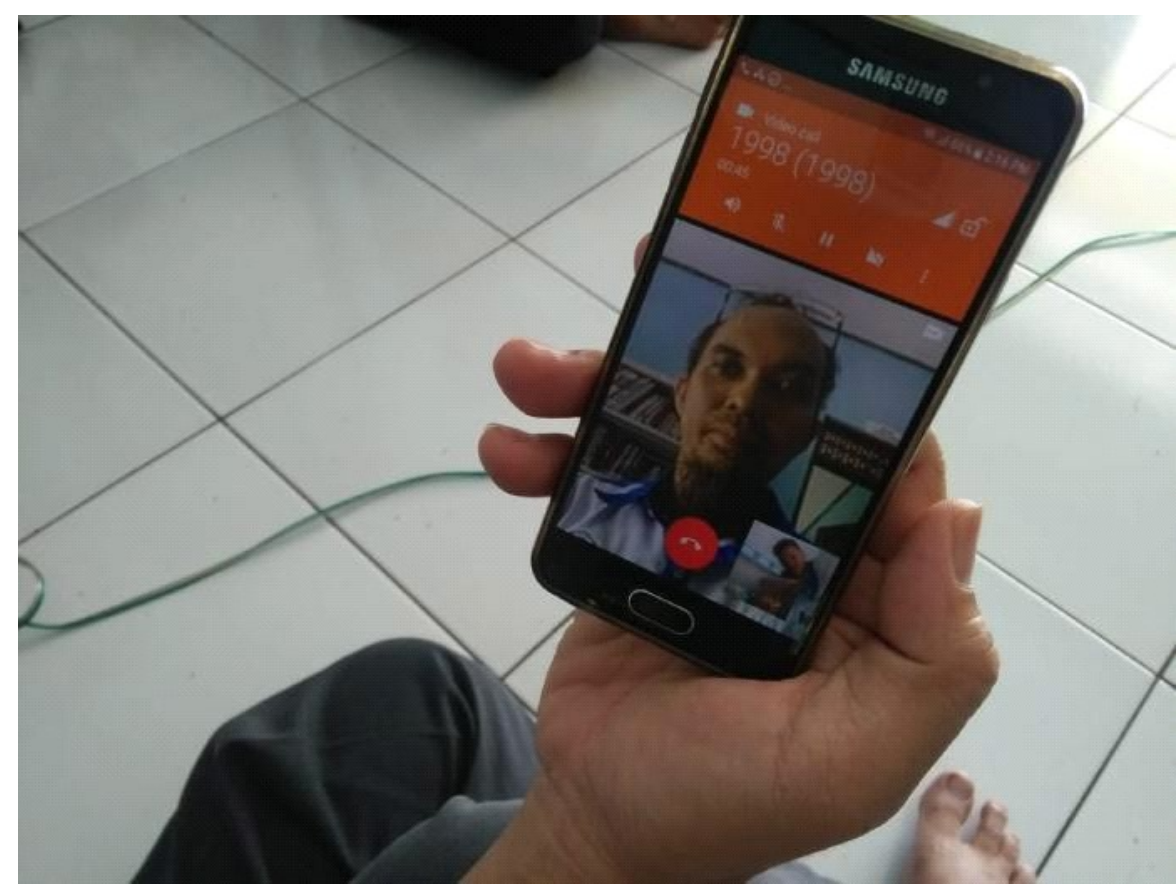

Gambar 11. Uji CobaVoIP Server

VoIP Server ini selanjutnya akan dipasang di tower yang telah dibangun di dekat kantor Desa Bamban Selatan.

\section{KESIMPULAN}

Berdasarkan kegiatan pengabdian kepada masyarakat yang telah dilaksanakan di kantor Desa Bamban Selatan, maka dapat diambil kesimpulan bahwa kegiatan telah berjalan dengan lancar dan mendapatkan antusias yang positif dari pegawai kantor desa karena dengan penerapan voice server sebegai fasilitas telpon gratis menggunakan wifi akan mempermudah komunikasi antara perangkat desa dalam menyelesaikan pekerjaan mengelola data kependudukan, data mata pencaharian, serta menampilkan informasi-informasi yang berkaitan dengan kegiatan desa yang telah dilaksanakan.

\section{DAFTAR PUSTAKA}

Afriani, K., \& Wahid, F. (2009). Dampak E-Government terhadap Good Governance : Temuan Empiris Dikota Jambi. Seminar Nasional Aplikasi Teknologi Informasi 2009 (SNATI 2009). Yogyakarta.

Asyikin, A. N., Fitri, R., \& Nugroho, A. S. (2015). Pengukuran Tingkat Kesiapan Kantor Pemerintahan Desa Dalam Penerapan Masterplan Teknologi Informasi Dan Komunikasi (TIK) Perkantoran Desa Menggunakan Kerangka Kerja Cobit. Seminar Nasional Hasil Penelitian dan Pengabdian Pada masyarakat (SNHP3M). Jakarta.

BATAN. (2011). Master Plan E_Government di Badan Teknologi Nuklir Nasional (BATAN) 2011-2014. Jakarta. 
Djumadal, J. S. (2005). Penerapan E-Government dan Berbagai Kendala di Pemerintahan Provinsi Daerah Istimewa Yogyakarta. Prosiding Konferensi Nasional Teknologi Informasi dan Komunikasi Indonesia, ITB. Bandung.

Fitri, R., Asyikin, A., \& Nugroho, A. B. (2017). Pengembangan Sistem Informasi Desa Untuk Menuju Tata Kelola Desa Yang Baik (Good Governance) Berbasis Teknologi Informasi Dan Komunikasi. Jurnal Sistem dan Teknologi Informasi, 99-105.

Hartono, Hartono, D., \& Mulyanto, E. (2010). Electronic Government Pemberdayaan Pemerintah dan Potensi Desa berbasis Web. 6, Nomor 1. Inpres_No_3_tahun_2003. (2003). Instruksi Presiden No 3 tahun 2003 Tentang Kebijakan dan Strategis Nasional Pengembangan E-Government. Pemerintah Republik Indonesia.

Praditya, D. (2014). Pemanfaatan Teknologi Informasi dan Komunikasi (TIK) di Tingkat Pemerintahan Desa. Vol. 17 No.2.

Sutardjo. (2015). Sistem Informasi Desa dan Kawasan Upaya Percepatan Kemandirian Desa. Kompasiana.com.

UU_6. (2014). Undang-Undang Nomor 6 Tahun 2014.

UU_RI_No_11_tahun_2008.(2008). UU RI No 11 Tahun 2008 Tentang Informasi dan Transaksi Elektronik. Pemerintah Republik Indonesia. 